\title{
The Correlation Between Dietary Pattern and Health Status Among Elderly Patients with Diabetes
}

\author{
$1^{\text {st }}$ Ema Wahyu Ningrum \\ Nursing Department \\ Harapan Bangsa University \\ Purwokerto, Indonesia \\ ema@uhb.ac.id
}

\author{
$2^{\text {nd }}$ Amin Susanto \\ Nursing Department \\ Harapan Bangsa University \\ Purwokerto, Indonesia \\ amin@uhb.ac.id
}

\begin{abstract}
The prevalence of diabetes mellitus increases as someone grows older. This increase is related to changes in lifestyle, including smoking, alcohol consumption, physical activity, eating patterns that lacks of vegetables and fruits, obesity, hypertension, and hypercholesterolemia. This study aims to determine the correlation between diet and the health status of elderly patients with diabetes mellitus. This research is a quantitative study with cross sectional design. The sampling technique used was a quota sampling which generated 50 elderly patients with Diabetes Mellitus. Univariate analysis was in the form of frequency distribution, and bivariate analysis used chi square. The instruments were a dietary questionnaire, stature meter and stepping scales to measure BMI, metlin to measure pelvic circumference, and easy touch sticks to assess fasting blood sugar levels and blood cholesterol levels. The results showed that most DM patients aged $\geq 60$ years (60\%), had elementary education (74.0\%), had a family history of Diabetes Mellitus (62\%), were female (92\%), had a good diet (58.0\%), had high blood sugar levels $(84.0 \%)$, obese body mass index (36\%), high limit cholesterol levels (46\%), central obesity (84\%). Eating patterns are not related to fasting blood sugar levels ( $p$ value $=0.828)$, are not related to cholesterol levels $(p$ value $=0.088)$, are associated with obesity ( $p$ value $=$ $0.025)$, are not related to central obesity ( $p$ value $=$ $0.441)$.
\end{abstract}

Keywords: dietary pattern, elderly health status, diabetes mellitus

\section{INTRODUCTION}

Diabetes Mellitus (DM) is one of the major health problems. The International Diabetes Federation (IDF) estimates that there are 382 million people living with diabetes in the world in 2013. By 2035 that number is expected to increase to 592 million. It is estimated that of the 382 million people, 175 million of them have not been diagnosed, so that they are threatened to progressively develop into unconscious and uncomplicated complications [1]. Indonesia ranks 6th in the highest incidence of
Diabetes Mellitus in the world [2] and based on the national data, diabetes mellitus rose from $6.9 \%$ to $8.5 \%$ [3].

Epidemiological studies show that the prevalence of both diabetes mellitus and impaired glucose tolerance (GTG) increases with age, settling before finally decreasing. Based on WHO data it was found that after reaching the age of 30 years, blood glucose levels would rise $1-2 \mathrm{mg} \%$ / year during fasting and would rise by $5-6 \mathrm{mg} \%$ / year at 2 hours after eating. Along with the process of aging, more and more elderly people are at risk of developing DM, so that now the term prediabetes is known.

Prediabetes is a condition of high fasting blood sugar $100-125 \mathrm{mg} / \mathrm{dL}$ or impaired glucose tolerance (blood sugar levels 140-199 mg / dL, 2 hours after loading $75 \mathrm{~g}$ glucose). When the sugar level reaches $\geq 200 \mathrm{mg} / \mathrm{dL}$, it is included in the Diabetes Mellitus class. Based on the results of Riskesdas in 2018, the highest prevalence of Diabetes Mellitus was within the age range of 55-74 years old with $19.6 \%$. The prediabetes proportion with Disturbed Sugar Tolerance (TGT) and Disturbed Fasting Blood Sugar (GDPT) in the age range $65-74$ years by $37.5 \%$.

Diabetes Mellitus is usually called the silent killer because this disease can affect all organs of the body and cause various kinds of complaints. Diseases that will be caused include impaired eye vision, cataracts, heart disease, odd pain, sexual impotence, wounds that are difficult to heal/ gangrene, lung infections, blood vessel disorders, strokes and so on. Not infrequently, DM patients who have severe amputations of limbs due to decay [4]. Diabetes is also known as "Mother of Disease" because it is the mother of other diseases such as hypertension, heart and blood vessel disease, stroke, kidney failure and blindness. Diabetes Mellitus can attack all levels of age and socioeconomic. If left unchecked, this disease can cause other complications that endanger health. 
The increase in the prevalence of noncommunicable diseases is associated with changes in lifestyle, including smoking, consumption of alcoholic beverages, physical activity, and eating patterns that lack of vegetables and fruits, obesity, hypertension, and hypercholesterolemia [1]. As we age, the elderly suffers from physical and mental setbacks that have many consequences. In addition, the elderly also experiences special problems that are more susceptible to macrovascular and microvascular complications than DM and the presence of geriatric syndrome. Lifestyle modification includes maintaining a good diet, exercise and weight loss can slow the progression of prediabetes to DM..

Diet is a way or effort in regulating the amount and type of food with a specific purpose such as maintaining health, nutritional status, preventing or helping cure diseases. Daily diet is a person's diet related to daily eating habits. Eating patterns or consumption patterns are the arrangement of types and amounts of food consumed by a person or group of people at a certain time [5].

An increase in DM sufferers is due to changes or transition of eating patterns, that is from traditional foods that are healthy, high in fiber, low in fat, low in calories to increasing consumption of foods containing calories such as simple carbohydrates, fat, red meat and low in fiber. A diet that is rich in energy and low in fiber will increase weight gain and insulin resistance, increase the rise in blood sugar after a meal and triglyceride levels in the blood. A healthy diet for diabetes is $25-30 \%$ fat, $50-55 \%$ carbohydrate, and $20 \%$ protein [5].

Carbohydrate metabolic disorders in the elderly include three things, they are insulin resistance, loss of insulin release of the first phase so that the initial surge in postpandrial insulin does not occur in the elderly with DM, increased postpandrial glucose levels with normal fasting blood glucose levels, of the three disorders, the most important role is insulin resistance, which is indicated by plasma insulin levels are quite high at 2 hours after loading 75 grams of glucose with high glucose levels as well. This condition is caused by changes in body composition (less muscle mass and more fat tissue), decreased physical activity, changes in diet, eating more carbohydrates due to reduced number of teeth [6].

In addition to disorders of glucose metabolism, DM also occurs in metabolic disorders of lipid metabolism so that there can be an increase in body weight to obesity, and even hypertension can also occur. If all three occur in a patient, then the patient has a metabolic syndrome. DM is considered a risk factor equivalent to coronary heart disease, so dyslipidemia in DM must be managed aggressively by achieving the target LDL cholesterol level 100mg
/ dl. Many studies show that decreasing cholesterol levels can reduce cardiovascular events in the elderly with DM [6].

Dietary arrangements in the form of a diet with high fiber, low glycemic index and low fat will reduce insulin resistance and the risk of DM. Fiber can reduce weight, reduce cholesterol levels and improve blood sugar profile [7].

Obesity, especially those that are central (the stomach) is one of the factors that influence the emergence of DM. Excessive fat deposits in the body can cause insulin resistance which affects the blood sugar levels of patients with diabetes mellitus [8]. One effort that can be done to reduce blood sugar levels in people with DM is to achieve good nutritional status. Determination of the ideal nutritional status used is the Body Mass Index (BMI). Research from Adnan (2013) shows that there is a correlation between BMI and blood sugar levels ( $\mathrm{p}=$ $0,000)[8]$.

Based on data from Padamara Community Health Center, Purbalingga the number of DM sufferers from January to December 2018 was 105 visits or around $8.7 \%$ of the total number of public visits. DM is the second highest number of noncommunicable diseases in this district. Based on this, researchers are interested in conducting research on the correlation of diet activity on blood sugar levels, cholesterol levels. and nutritional status of patients with elderly diabetes mellitus.

\section{METHODOLOGY}

This research was a quantitative study with cross sectional design. The sampling technique used quota sampling which generated 50 elderly patients with Diabetes Mellitus. Univariate analysis was in the form of frequency distribution, and bivariate analysis used chi square. The instruments were a dietary questionnaire, stature meter and stepping scales to measure BMI, metlin to measure pelvic circumference, and easy touch sticks to assess fasting blood sugar levels and blood cholesterol levels. .

\section{RESULTS AND DISCUSSION}

In this study the number of female DM sufferers is more than male. This is in line with a research by Lubis (2012) and Bintanah (2012) which show that type 2 DM sufferers are more common in women compared to men. When viewed from age, this study shows that respondents who have age $\geq 60$ years are the respondents who have the largest percentage. This is in line with the result of Awad's study (2011) which showed an increase in the number of DM patients in patients over than 50 years. The results of national data in 2018 also showed that the number of people with DM in Indonesia increased with age. 
Based on the latest education background, the majority of respondents graduated from elementary school. The higher level of education means that there is a possibility that someone has better knowledge in preventing diseases including DM, and vice versa.

In this study $62 \%$ of DM patients had a family history of DM. People who have one or more family members suffering from DM, are 2 to 6 times more likely to suffer from diabetes compared to people who do not have family members suffering from diabetes [9].

According to Suharjo (2008) diet is a variety of information that provides an overview of the type and amount of food eaten every day by one person and is characteristic for a group of people in meeting the need for food which includes attitudes, beliefs and food choices. Nugroho and Purwanti's research (2010) stated that respondents' blood sugar levels were mostly high because the respondents were indeed diabetes mellitus patients. But in addition to diabetes mellitus factor, another factor that influences blood sugar level is diet.

TABLE 1. Characteristics Of Respondents

\begin{tabular}{|l|c|r|}
\hline \multicolumn{1}{|c|}{ CHARACTERISTIC } & $\mathrm{f}$ & $\%$ \\
\hline AGE (Years) & & \\
$<45$ years old & 6 & 12,0 \\
$45-59$ years old & 14 & 28,0 \\
$\geq 60$ years old & 30 & 60,0 \\
Total & 50 & 100,0 \\
\hline EDUCATION & & \\
Elementary & 37 & 74,0 \\
Junior High School & 112 & 22,0 \\
Senior High School & 50 & 4,0 \\
Total & & 100,0 \\
\hline HISTORY OF DM & & \\
Yes & 31 & 62,0 \\
No & 19 & 38,0 \\
Total & 50 & 100,0 \\
\hline GENDER & & \\
Woman & 46 & 94,0 \\
Man & 4 & 6,0 \\
\hline
\end{tabular}

TABLE 2. Correlation Between Dietary Pattern And Health Status Of Elderly

\begin{tabular}{|l|l|l|l|l|l|}
\hline \multicolumn{7}{|c|}{ Fasting Blood Sugar Levels } \\
\hline & & Prediabetes & Diabetes & Total & $\begin{array}{l}P \\
\text { value }\end{array}$ \\
\hline $\begin{array}{l}\text { Dietary } \\
\text { Pattern }\end{array}$ & Enough & $\begin{array}{l}13 \\
(61.9 \%)\end{array}$ & $\begin{array}{l}8 \\
(38.1 \%)\end{array}$ & $\begin{array}{l}21 \\
(100 \%)\end{array}$ & $\begin{array}{l}0.82 \\
8\end{array}$ \\
\hline
\end{tabular}

\begin{tabular}{|c|c|c|c|c|c|}
\hline & Good & $\begin{array}{l}20 \\
(69.0 \%)\end{array}$ & $\begin{array}{l}9 \\
(31.0 \%)\end{array}$ & $\begin{array}{l}29 \\
(100 \%)\end{array}$ & \\
\hline \multicolumn{6}{|c|}{ Cholesterol Levels } \\
\hline & & $\begin{array}{l}\text { Border } \\
\text { height }\end{array}$ & $\begin{array}{l}\text { Hiper } \\
\text { cholest } \\
\text { erolemia }\end{array}$ & Total & $p$ value \\
\hline \multirow[t]{2}{*}{$\begin{array}{l}\text { Dietary } \\
\text { Pattern }\end{array}$} & Enough & $\begin{array}{l}19 \\
(90.5 \%)\end{array}$ & $\begin{array}{l}2 \\
(9.5 \%)\end{array}$ & $\begin{array}{l}21 \\
(100 \%)\end{array}$ & $\begin{array}{l}0.08 \\
8\end{array}$ \\
\hline & Good & $\begin{array}{l}19 \\
(65.5 \%)\end{array}$ & $\begin{array}{l}10 \\
(34.5 \%)\end{array}$ & $\begin{array}{l}29 \\
(100 \%)\end{array}$ & \\
\hline \multicolumn{6}{|c|}{ Obesity } \\
\hline & & Normal & Obesit y & Total & $p$ value \\
\hline \multirow[t]{2}{*}{$\begin{array}{l}\text { Dietary } \\
\text { Pattern }\end{array}$} & Enough & $\begin{array}{l}14 \\
(66.7 \%)\end{array}$ & $\begin{array}{l}7 \\
(33.3 \%)\end{array}$ & $\begin{array}{l}21 \\
(100 \%)\end{array}$ & $\begin{array}{l}0.02 \\
5\end{array}$ \\
\hline & Good & $\begin{array}{l}27 \\
(93.1 \%)\end{array}$ & $\begin{array}{l}2 \\
(6.9 \%)\end{array}$ & $\begin{array}{l}29 \\
(100 \%)\end{array}$ & \\
\hline \multicolumn{6}{|c|}{ Central Obesity } \\
\hline & & $\begin{array}{l}\text { Central } \\
\text { Obesity }\end{array}$ & Normal & Total & $p$ value \\
\hline \multirow[t]{2}{*}{$\begin{array}{l}\text { Dietary } \\
\text { Pattern }\end{array}$} & Enough & $\begin{array}{l}19 \\
(90.5 \%)\end{array}$ & $\begin{array}{l}2 \\
(9.5 \%)\end{array}$ & $\begin{array}{l}21 \\
(100 \%)\end{array}$ & $\begin{array}{l}0.44 \\
1\end{array}$ \\
\hline & Good & $\begin{array}{l}23 \\
(79.3 \%)\end{array}$ & $\begin{array}{l}6 \\
(20.7 \%)\end{array}$ & $\begin{array}{l}29 \\
(100 \%)\end{array}$ & \\
\hline
\end{tabular}

Based on the statistical tests, it can be concluded that there was no correlation between diet and fasting blood sugar levels in people with DM ( $\mathrm{p}$ value = 0.828). The result of this study is not in line with research from Susanti (2018) which shows that there is a correlation between diet and blood sugar levels $(\mathrm{p}$ value $=0.00)$. Eating patterns play an important role for people with diabetes mellitus. Someone who cannot regulate eating patterns with 3 settings (schedule, type and amount), then s/he may experience increased blood sugar levels. The diet of DM sufferers must really be considered. DM sufferers usually tend to have uncontrolled blood sugar content. Blood sugar levels will increase dramatically after consuming foods that contain lots of carbohydrates and / or sugar [10]. Therefore, people with DM need to maintain dietary settings in order to control blood sugar levels so that their blood sugar levels remain controlled [11].

Based on the result of the research that has been done, it shows that there is no correlation between diet and cholesterol levels ( $p>0.088$ ). Theory according to Sastriamidjojo states that consumption of food that is high in fat and cholesterol will increase total cholesterol and LDL levels. Nurrahmi's research result states that people who are at risk of having high cholesterol levels are those who adopt a diet that 
DIPUSKESMAS WAWONASA," J. e-Biomedik, vol 2, no. 2, 2014. grows older, the ability of LDL receptors will decrease so that LDL levels in the blood increase and will have an impact on the process of coronary arteries blockage. The ability of the receptors will decrease with age. LDL receptors are inhibiting factors (LDL cholesterol synthesis), and cholesterol synthesis will increase. Age above 45 years is the age range that is at risk for suffering from hypercholesterolemia [12].

In this study there is a correlation between diet and obesity ( $p$ value $<0.05$ ). The result of this study is in line with research from Shara Kurnia Trisnawati (2012) which states that there is a correlation between the incidence of DM with Body Mass Index (p 0.006 OR 0.14 ; 95\% CI 0.037-0.524). Within the old age, people tend to obese because of slow metabolism, lack of attention to body shape, frequent frequency of food consumption, and low physical activity [13]. Obese people are 7.14 times more likely to suffer from type 2 diabetes compared to people who are not obese. The influence of Body Mass Index on diabetes mellitus is caused by lack of physical activity and high consumption of carbohydrates, proteins and fats which are risk factors for obesity. This causes increased fatty acids or Free Fatty Acid (FFA) in cells. This increase in FFA will reduce the translocation of glucose transporters into the plasma membrane, and cause insulin resistance in muscle and adipose tissue [4].

In addition, the result of this study shows there is no correlation between diet and the incidence of central obesity ( $p$ value $=0.441>0.05$ ). This result is not in line with research from Fatimah which shows that high sucrose intake, high fat intake and low consumption of vegetables and fruit with central obesity [14].

\section{CONCLUSION}

The patient's health status is seen from blood sugar levels, cholesterol levels, obesity and central obesity Dietary patterns are not related to fasting blood sugar levels ( $\mathrm{p}$ value $=0.828$ ), are not related to cholesterol levels ( $\mathrm{p}$ value $=0.088$ ), are associated with obesity ( $\mathrm{p}$ value $=0.025)$, and are not related to central obesity ( $p$ value $=0.441)$. It is suggested that people should regularly check their monthly blood sugar level, cholesterol level, and anthropometry.

\section{REFERENCES}

[1] K. RI, Infodatin Pusat data dan Informasi Kementerian Kesehatan RI. Jakarta, 2014.

[2] R. Betteng, "ANALISIS FAKTOR RESIKO PENYEBAB TERJADINYA DIABETES MELITUS TIPE 2 PADA WANITA USIA PRODUKTIF
[3] Badan Penelitian dan Pengembangan Kesehatan (Riskesdas) 2017-2018. Jakarta: Kemenkes RI, 2017.

[4] S. Setyorogo and S. . Trisnawati, "Faktor Resiko Kejadian Diabetes Melitus Tipe II Di Puskesmas Kecamatan Cengkareng Jakarta Barat Tahun 2012,” J. Ilm. Kesehat., vol. 5, no. 1, pp. 6-11, 2013.

[5] A. Sudaryanto, N. A. Setiyadi, and D. A. Frankilawati, "HUBUNGAN ANTARA POLA MAKAN, GENETIK DAN KEBIASAAN OLAHRAGA TERHADAP KEJADIAN DIABETES MELITUS TIPE II DI WILAYAH KERJA PUSKESMAS NUSUKAN, BANJARSARI," Pros. SNST Fak. Tek., vol. 1, no. 1, 2014.

[6] I. Kurniawan, K. Usila, P. Pangkalbalam, and K. B. Belitung, "Diabetes Melitus Tipe 2 pada Usia Lanjut," 2010.

[7] S. Bintanah and E. Handarsari, "Asupan Serat dengan Kadar Gula Darah, Kadar Kolesterol Total dan Status Gizi Pada Pasien Diabetus Mellitus Tipe 2 Di Rumah Sakit Roemani Semarang," Lppm Unimus, vol. 001, pp. 289-297, 2012.

[8] M. Adnan, T. Mulyati, and J. T. Isworo, "Hubungan Indeks Massa Tubuh (IMT) Dengan Kadar Gula Darah Penderita Diabetes Mellitus (DM) Tipe 2 Rawat Jalan Di RS Tugurejo Semarang," J. Gizi Univ. Muhammadiyah Semarang, vol. 2, no. 1, pp. 18-24, 2013.

[9] J. S. Kekenusa, B. T. Ratag, and G. Wuwungan, "ANALISIS HUBUNGAN ANTARA UMUR DAN RIWAYAT KELUARGA MENDERITA DM DENGAN KEJADIAN PENYAKIT DM TIPE 2 PADA PASIEN RAWAT JALAN DI POLIKLINIK KANDOU MANADO."

[10] S. Susanti and D. N. Bistara, "Hubungan Pola Makan Dengan Kadar Gula Darah Pada Penderita Diabetes Mellitus," J. Kesehat. Vokasional, 2018.

[11] N. Alcubierre et al., "Relationship of the adherence to the Mediterranean diet with health-related quality of life and treatment satisfaction in patients with type 2 diabetes mellitus: a post-hoc analysis of a crosssectional study," Health Qual. Life Outcomes, vol. 14, no. 1, p. 69, Dec. 2016.

[12] A. Yoeantafara and S. Martini, "Pengaruh Pola Makan Terhadap Kadar Kolesterol Total," Media Kesehat. Masy. Indones., vol. 13, no. 4, p. 304, 2017.

[13] K. (2019). Mellitus, D., Di, H., Kerja, W., \& Salatiga and 15-23., "Gambaran Pola Makan Sebagai Penyebab Kejadian Penyakit Tidak Menular," pp. 15-23, 2019.

[14] F. Z. Burhan, S. Sirajuddin, and R. Indriasari, "PEGAWAI PEMERINTAHAN DI KANTOR BUPATI KABUPATEN JENEPONTO Consumption Pattern Towards the Incidence of Central Obesity in Employee of Government in Bupati Office Jeneponto Masalah overweight dan obesitas meningkat dengan cepat di berbagai belahan dunia me," Penelitian, pp. 114,2005 Kementerian Kesehatan RI, Riset Kesehatan Dasar PENYAKIT DALAM BLU RSUP PROF. DR. R.D 